\title{
Risk factors of skin cancer among Indonesian population
}

Joedo Prihartono ${ }^{1}$, Setyawati Budiningsih ${ }^{1}$, Yoshiyuki Ohno ${ }^{2}$, Mochtar Hamzah $^{3}$, Masamitsu Ichihashi $^{4}$, Evert Poetiray ${ }^{5}$, Mpu Kanoko ${ }^{6}$, Masato Ueda ${ }^{4}$, Achmad Tjarta ${ }^{6}$, Herman Cipto $^{3}$, Arman Mukhtar ${ }^{5}$, Nobuo Munakata ${ }^{7}$, Santoso Cornain ${ }^{6}$

\begin{abstract}
Abstrak
Suatu penelitian kasus kontrol untuk mengkaji faktor risiko kejadian kanker kulit telah dilaksanakan pada populasi Indonesia menggunakan 139 kasus baru kanker kulit dan 242 pasangan kontrol di RS Cipto Mangunkusumo Jakarta. Kriteria pasangan kontrol adalah umur, jenis kelamin, dan status sosial ekonomi. Tujuh belas faktor risiko yang diteliti adalah: indeks masa tubuh, tingkat pendidikan, kerja di lapangan terbuka, alat keamanan diri, faktor genetik, kebiasaan merokok, pajanan pada perokok, penggunaan hormon, dan konsumsi sembilan jenis bahan makanan. Studi ini telah mengidentifikasi 7 faktor penyebab kanker kulit yakni: pendidikan rendah (OR 9.71), kerja di lapangan (OR 5.29), berat badan rendah (OR 2.93), riwayat kanker keluarga (OR 2.82), perokok (OR 2,04), pajanan pada perokok (OR 2.06) dan konsumsi tinggi lemak (OR 4.47). Studi ini juga mengidentifikasi 8 faktor pencegah yakni: penggunaan baju lengan panjang (OR 0.29), konsumsi cukup daging (OR 0.17). konsumsi cukup lemak (OR 0.44), konsumsi tinggi atau cukup telur (OR 0.05 dan 0.19), konsumsi tinggi dan cukup santan (OR 0.44 uan 0.24), konsumsi tinggi buah (OR 0.29), konsumsi tinggi dan cukup sayuran (OR 0.54 dan 0.34), serta konsumsi tinggi bawang putih (OR 0.44). Analisa lanjuan dengan metoda regresi logistik menunjukkan hanya 6 faktor saja yang nyata berkaitan dengan perkembangan kanker kulit, yakni pendidikan, pekerjaan di luar, konsumsi lemak, daging, telur dan buah-buahan.
\end{abstract}

\begin{abstract}
A case-control study to identify risk factors on the development of skin cancer among Indonesian population has been conducted using 139 newly diagnosed skin cancer cases, and 242 matched contrcls selected among non-cancer patients of the Jakarta General Hospital. The matching variabies are age interval. sex, and social-economic status. Seventeen potential determinant factors were assessed: present body mass index, education, working condition, physical protection, genetic trait, smoking habit, exposure to smokers, hormonal drug, and consumption of nine food items. This study has identified seven significant risk factors: low education $(O R=9.71)$, working in the open field $(O R=5.29)$, under weight $(O R=2.93)$, cancer history $(O R=2.82)$, smoking $(O R=2.04)$, exposure to smokers $(O R=2.06)$, and high fat consumption $(O R=4.47)$. This study also has identified eight significant protective factors: using iong sleeve $(O R=0.29)$, moderate consumption of meat $(O R=0.17)$, moderate consumption of fai $(O R=0.44)$, high and moderate consumption of egg $(O R=0,05$ and 0,19 respectively), high and moderate consumption of coconut milk $(O R=0,44$ and 0,24 respectively), high consumption of fruit $(O R=0,29)$, high and moderate consumption of vegetable $(O R=0,54$ and 0,34 respectively), and high consumption of garlic $(O R=0.44)$. Further analysis using logistic regression method revealed those 6 factors, namely education, working outside, fat, meat, egg and fruit consumption have real effect on the development of skin cancer.
\end{abstract}

Keywords: case-control, skin cancer, and risk factor

' Department of Community Medicine, Faculty of Medicine, University of Indonesia, Jakarta 10320, Indonesia

${ }^{2}$ Department of Preventive Medicine, Nagoya University School of Medicine, Nagoya 466-8550, Japan

${ }^{3}$ Department of Dermatology, Faculty of Medicine, University of Indonesia, Jakarta 10430, Indonesia

${ }^{4}$ Department of Dermatology, Kobe University School of Medicine, Kobe 650-0017, Japan

${ }^{5}$ Department of Surgery, Faculty of Medicine, University of Indonesia, Jakarta 10430, Indonesia

${ }^{6}$ Department of Anatomic Pathology, Faculty of Medicine, University of Indonesia, Jakarta 10430, Indonesia

${ }^{7}$ Radiobiology Division, National Cancer Center Research Institute, Tokyo 104-0045, Japan
As one of the developing countries with fast economical growth, Indonesia also showed a dramatic improvement of its public health situation. In the last decade there was a significant shift of leading causes of death, from acute communicable diseases in early 1980s to chronic diseases in early 1990s. Coronary heart disease and malignancies ranked number one and two in this statistical figure. ${ }^{1,2}$

Indonesia is located just in the equator with very dense sunlight exposure for almost all of its population. Inspite of recent development of industry, agriculture remained the larger contribution to the 
economy of the country. According to demographic statistic, $70 \%$ of Indonesian adults still engaged with one type of agricultural works and the exposure with lengthy and direct sunlight was widely common.

The pathology-based cancer registry in 1988-1992 showed that skin cancer ranked the first among male cases and ranked the fourth among/ female cases. ${ }^{3}$ Most of these cases came to the hospital at very late stages and showed poor responses to the available treatments. In contrast, the majority of skin cancer in Japan were in earlier stage. ${ }^{4}$

Besides exposure to direct sunlight, other risk factors could influence the development of skin cancer. The excessive use of cosmetics, hormonal drugs, certain skin types, and genetic trait could increase the risk of skin cancer, while the use of skin protectors could reduce the level of risk. In preparing the proper educational material, a thorough study on such risk factors among the Indonesian population might reveal specific data, both geographical and ethnical one.

The importance of environinental and constitutional risk factors has been studied mostly in populations living in cooler climates. ${ }^{4 \cdot 9}$ This study was intended to identify significant risk factors and lifestyles influencing the development of skin cancer in tropical area.

\section{MATERIALS AND METHODS}

A case-control study design ${ }^{11,12}$ with 1:2 ratio was implemented in the assessment of skin cancer's risk factors. The case group was defined as all new diagnosed skin cancer patients who came to Dr. Cipto Mangunkusumo National Central General Hospital, Jakarta during the study period of 1996 to 1999. Almost all of skin cancer patients in the Jakarta area, especially those from middle to lower social economic level, were referred to this hospital. The diagnosis of skin cancer was performed histopathologically. Standard coding system ${ }^{10}$ was used throughout the study period. The controls were defined as non-malignancy patients who came for medical assistance to the dermatology or surgery departments of the General Hospital in similar (within 3 months) to the cases. For every skin cancer patient, two hospital controls matched for age (ca. 3 yrs) and gender were used to increase its statistical power. Demographic characteristics of the respondents were gathered through a structured interview, while medical data were collected through physical examination. Standard questionnaire and its manual are given in Appendix.

The seventeen risk factors included in this study were present body mass index, education, working condition, physical protection, genetic trait, smoking habit, hormonal drug, and consumption of nine food items. Each potential risk factor was assessed through bivariate analysis and was measured its estimated Relative Risk and the $95 \%$ confidence intervals. For all significant risk factors, a further analysis has been applied to assess the strength of association for each determinant factor given that all other factors retained as constant. Logistic regression method was selected for this multivariate analysis.

Nutritionai factors were adjusted to the Indonesian diet. $^{13}$ High food consumption was defined if the subject consumed more than twice per week, moderate consumption was twice or less per week. Low educational level was defined for those who only had elementary education, middle education was junior high schcol. Physical protection was defined for subject who regularly wore long sleeve shirt. Smoking risk was defined as those who currently smoking cigarettes. Genetic trait was defined for those who had relative suffering from any type of malignancy.

\section{RESULTS}

So far, until March 1999, data of 139 cases of skin cancer and 242 controls could be analyzed. Female subjects are a little bit more than male subjects; almost $57 \%$ of cases are female skin cancer patients. As expected earlier, the majority of cases were rather older. Almost $44 \%$ were older than 60 years, followed by around $30 \%$ of cases between 51 and 60 years of age. There were almost $9 \%$ of skin cancer cases aged less than 40 years. The details are given in Table 1.

Table 1. Age distribution of cases and controls

\begin{tabular}{lcccc}
\hline \multirow{2}{*}{ Variables } & \multicolumn{2}{c}{ Cases } & \multicolumn{2}{c}{ Controls } \\
\cline { 2 - 5 } & $\mathrm{N}$ & $\%$ & $\mathrm{~N}$ & $\%$ \\
\hline Gender Distribution & & & & \\
$\quad$ Male & 60 & 43.2 & 97 & 40.1 \\
$\quad$ Female & 79 & 56.8 & 145 & 59.9 \\
Age Distribution & & & & \\
$\quad$ Less than 40 years & 12 & 8.6 & 24 & 9.5 \\
$\quad$ Between 40-50 years & 25 & 18.0 & 41 & $17 . j$ \\
$\quad$ Between 51 - 60 years & 41 & 29.5 & 84 & $3 .$. \\
$\quad$ More than 60 years & 61 & 43.9 & 93 & 7.4 \\
\hline
\end{tabular}


The selection of controls did not interfere with the possible determinant factors. No control subject was diagnosed of having any disease that has confirmed causal association with any potential factor, whether increasing or decreasing association. The majority of control group were women who visit the hospital for consultation. Eighty-four percents of control visited dermatology department seeking for medical assistance for ordinary medical problems. See Figure 1 for their clinical diagnosis.
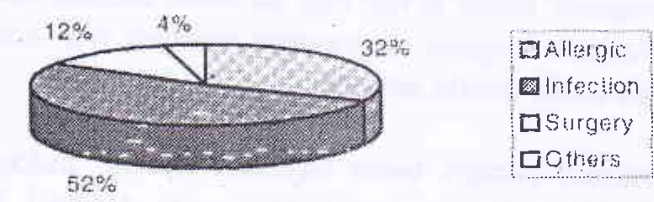

Figure 1. Clinical diagnosis of controls
Univariate analysis of determinant factors showed that fourteen of them had significant role on the development of skin cancer. The results of the analysis of social, demographical and environmental factors are given in Table 2. Lower educational level significantly $(O R=9.7)$ increased the risk of contracting skin cancer, working outside at the open area also significantly $(\mathrm{OR}=5.3)$ caused the malignancy. Under weight, having relative with cancer, smoking, and exposure to active smokers also showed significant risk, though not too strong (OR between 2.04 and 2.93) in the skin cancer development. On the other hand, the use of long sleeve can significantly reduced $(O R=0.29)$ the risk of skin cancer. The use of hormonal drugs such as contraceptive methods and other hormonal medicines did not give any significant effect in the development of skin cancer.

Table 2. Statistical analysis of social demography and environmental factors

\begin{tabular}{|c|c|c|c|c|c|}
\hline \multirow[t]{2}{*}{ Variables } & \multirow[t]{2}{*}{ Case } & \multirow[t]{2}{*}{ Control } & \multirow[t]{2}{*}{ OR } & \multicolumn{2}{|c|}{$95 \% \mathrm{CI}$} \\
\hline & & & & Min & Max \\
\hline \multicolumn{6}{|l|}{ Educational Level } \\
\hline Low ( Elementary ) * & 109 & 72 & 9.71 & 5.19 & 18.36 \\
\hline Middle ( Junior High ) & 13 & 61 & 1.37 & 0.58 & 3.21 \\
\hline High ( Senior High up ) & 17 & 109 & 1 & & \\
\hline \multicolumn{6}{|l|}{ Working Outside } \\
\hline Yes & 69 & 38 & 5.29 & 3.19 & 8.81 \\
\hline No & 70 & 204 & 1 & & \\
\hline \multicolumn{6}{|l|}{ Body Type } \\
\hline Under weight $(\mathrm{BMI}<17)$ * & 85 & 97 & 2.93 & 1.71 & 5.03 \\
\hline Normal weight (BMI $17-22$ ) & 29 & 97 & 1 & & \\
\hline Over weight $(\mathrm{BMI}>22)$ & 25 & 48 & 1.74 & 0.88 & 3.46 \\
\hline \multicolumn{6}{|l|}{ Cancer History** } \\
\hline Yes * & 6 & 0 & 2.82 & 2.46 & 3.23 \\
\hline No & 133 & 242 & 1 & & \\
\hline \multicolumn{6}{|l|}{ Hormonal Use } \\
\hline Ever use & 3 & 12 & 0.42 & 0.09 & 1.65 \\
\hline Never & 136 & 230 & 1 & & \\
\hline \multicolumn{6}{|l|}{ Smoking Habit } \\
\hline Smoker * & 32 & 33 & 2.04 & 1.14 & 3.67 \\
\hline Ex smoker & 22 & 30 & 1.54 & 0.80 & 2.96 \\
\hline Non smoker & 85 & 179 & 1 & & \\
\hline \multicolumn{6}{|l|}{ Exposure to Smokers } \\
\hline Yes * & 62 & 68 & 2.06 & 1.30 & 3.26 \\
\hline No & 77 & 174 & 1 & & \\
\hline \multicolumn{6}{|l|}{ Use of Long sleeves } \\
\hline Yes * & 59 & 174 & 0.29 & 0.18 & 0.46 \\
\hline No & 80 & 68 & 1 & & \\
\hline
\end{tabular}

* Significant risk assessed based on $95 \%$ Confidence Interval; OR = Odds Ratio; $95 \% \mathrm{CI}=95 \%$ Confidence Interval

** Calculated using Relative Risk Formula 
The results of the analysis of nutritional factors are given in Table 3. From nine types of food, only seven influenced the development of skin cancer. Protection from the development of skin was shown by moderate consumption of lean meat $(\mathrm{OR}=0.17)$, egg frequently or moderately ( $\mathrm{OR}=0.05$ and 0.19 respectively), food or drink with coconut milk either daily or moderately with $\mathrm{OR}=0.44$ and 0.24 respectively. Consumption of fresh fruit and vegetables as expected also to provide protection against skin cancer. Fresh fruit consumed almost every day showed significant $(\mathrm{OR}=0.29)$ protection against skin cancer, similarly for fresh vegetable consumed moderately or every day with $\mathrm{OR}=0.34$ and 0.54 , respectively. The use of garlic in every day recipe could also be a protective factor $(\mathrm{OR}=0.44)$ for skin cancer.

Fat consumption showed a very interesting impact in the development of skin cancer. Subjects who consumed high fat showed significantly higher risk $(\mathrm{OR}=4.47)$ of developing skin cancer. On the contrary, those who consumed moderate portion of fatty food showed reduce risk with an $\mathrm{OR}=0.44$.

Milk consumption and tea consumption did not have any significant impact to the development of skin cancer. The majority of cases and controls did not consume much of milk but almost all of them consumed tea frequently.

Table 3. Statistical analysis of nutritional factors

\begin{tabular}{|c|c|c|c|c|c|}
\hline \multirow[t]{2}{*}{ Variables } & \multirow[t]{2}{*}{ Case } & \multirow[t]{2}{*}{ Control } & \multirow[t]{2}{*}{ OR } & \multicolumn{2}{|c|}{$95 \% \mathrm{CI}$} \\
\hline & & & & Min & Max \\
\hline Milk Consumption & & & & & \\
\hline Always ( $>2$ times peı week) & 6 & 17 & 0.56 & 0.19 & 1.58 \\
\hline Rarely (twice or less per week) & 13 & 36 & 0.58 & 0.28 & 1.18 \\
\hline Almost never & 120 & 192 & 1 & & \\
\hline Tea Consumption & & & & & \\
\hline Always ( $>2$ times per week) & 109 & 181 & 1.43 & 0.73 & 2.82 \\
\hline Rarely (twice or less per week) & 14 & 23 & 1.45 & 0.54 & 3.84 \\
\hline Almost never & 16 & 38 & 1 & & \\
\hline Meat Consumption & & & & & \\
\hline Always ( $>2$ times per week) & 16 & 23 & 0.50 & 0.23 & 1.09 \\
\hline Rarely (twice / less per week) * & 37 & 157 & 0.17 & 0.10 & 0.28 \\
\hline Almost never & 86 & 62 & 1 & & \\
\hline Fat Consumption & & & & & \\
\hline Always ( $>2$ times per week) * & 18 & 6 & 4.47 & 1.59 & 13.13 \\
\hline Rarely (twice / less per week) * & 29 & 99 & 0.44 & 0.26 & 0.73 \\
\hline Almost never & 92 & 137 & 1 & & \\
\hline Egg Consumption & & & & & \\
\hline Always $(>2$ times per week) $*$ & 14 & 99 & 0.05 & 0.02 & 0.11 \\
\hline Rarely (twice / less per week) * & 78 & 128 & 0.19 & 0.10 & 0.39 \\
\hline Almost never & 47 & 15 & 1 & & \\
\hline Coconut Milk Consumption & & & & & \\
\hline Always ( $>2$ times per week) $*$ & 19 & 30 & 0.44 & 0.20 & 0.92 \\
\hline Rarely (twice / less peı week) * & 59 & 170 & 0.24 & 0.14 & 0.40 \\
\hline Almost never & 61 & 42 & 1 & & \\
\hline Fruit Consumption & & & & & \\
\hline Always $(>2$ times per week $) *$ & 45 & 132 & 0.29 & 0.14 & 0.58 \\
\hline Rarely (twice or less per week) & 67 & 87 & 0.66 & 0.33 & 1.31 \\
\hline Almost never & 27 & 23 & 1 & & \\
\hline Vegetable Consumption & & & & & \\
\hline Always (>2 times per week) $*$ & 34 & 62 & 0.54 & 0.30 & 0.96 \\
\hline Rarely (twice or less per week) * & 41 & 117 & 0.34 & 0.20 & 0.58 \\
\hline Almost never & 64 & 63 & 1 & & \\
\hline Garlic Consuption & & & & & \\
\hline Always $(>2$ times per week)* & 54 & 143 & 0.44 & 0.22 & 0.88 \\
\hline Rarely (twice or less per week) & 62 & 72 & 1.01 & 0.50 & 2.04 \\
\hline Almost never & 23 & 27 & 1 & & \\
\hline
\end{tabular}

* Significant risk assessed based on $95 \%$ Confidence Interval; OR = Odds Ratio; $95 \% \mathrm{CI}=95 \%$ Confidence Interval 
When logistic regression analysis method was applied for the fourteen significant risk factors, seven of them did not show real impact on skin cancer. By keeping other risk factors constant, the causal relationship of body type, cancer history, smoking, exposure to smokers, use of long sleeve, coconut milk, vegetable and garlic consumption diminished. Low education, working outside, and high fat consumpition remained as significant risk factors for the development of skin cancer, while meat, egg, and fruit consumption also remained as significant protector against skin cancer. See details in Table 4.

\section{DISCUSSION}

The development of skin cancer is influenced by multi factors consisting of intrinsic and extrinsic components. The intrinsic factor of cancer history among family member was detected as significant risk factor in the univariate analysis, but diminished after being adjusted with other risk factors. Consumption of various food items also showed unique phenomenon in the development of skin cancer. Protein rich food consumption such as meat and egg proved to be effective in preventing skin cancer both in uni- and multivariate analyses. This important food component might play a role in prevention or in the recovery process of any skin cell damage due to exposure to extrinsic factors such as sunlight.
Other food related protective factors such as vegetabie, garlic and coconut milk only showed significant protection in the univariate analysis and diminished in the multivariate analysis. Fruit consumption that provides abundant mineral needed for assisting the metabolism of other micro-nutrient in the skin repair remained significant in the adjustment process. Fat consumption showed different effect depending on its level of consumption. High fat consumption increased significantly the development of skin cancer as in other types of malignancies. However, moderate consumption of fat showed protective defect.

The extrinsic factors of active and passive smokers tend to be significant only after interacting with other determinant factors. These cigarette-related determinant factors loss their influences after adjustment. Low body mass index role in the deveiopment of skin cancer was also diminished in the logistic regression analysis. Low education showed very strong relationship with the development of skin cancer. Persons with low education tended to have occupation types that give higher suniight exposure outside the buildings. Both determinant factors, low education and working outdoors, persistently showed significant increased risk for the development of skin cancer. On the other hand, the use of long sleeve shirt as protector for excessive sunlight only significantly prevents skin cancer before adjustment with other determinant factors. The data confirmed the other studies. ${ }^{7-9,14-17}$

Table 4. Estimated Relative Risk of determinant factors

\begin{tabular}{|c|c|c|c|c|c|c|}
\hline \multirow[t]{2}{*}{ Determinant Factors } & \multicolumn{3}{|c|}{ Bivariate } & \multicolumn{3}{|c|}{ Multivariate } \\
\hline & $\mathrm{OR}$ & \multicolumn{2}{|c|}{$95 \% \mathrm{CI}$} & OR & \multicolumn{2}{|c|}{$95 \% \mathrm{Cl}$} \\
\hline Education (low level) & $9.71 *$ & 5.19 & 18.36 & $9.56 *$ & 5.45 & 19.21 \\
\hline Working outside & $5.29 *$ & 3.19 & 8.81 & $7.45 *$ & 2.98 & 9.43 \\
\hline Body type (Under weight) & $2.93 *$ & 1.71 & 5.03 & 1.98 & 0.99 & 4.35 \\
\hline Having cancer history & $2.82 *$ & 2.46 & 3.23 & 1.87 & 0.96 & 4.12 \\
\hline Smoking (active smoker) & $2.04 *$ & 1.14 & 3.67 & 1.99 & 0.99 & 3.88 \\
\hline Exposure to smokers & $2.06 *$ & 1.30 & 3.26 & 1.65 & 0.95 & 3.43 \\
\hline Use of long sleeve & $0.29 *$ & 0.18 & 0.46 & 0.56 & 0.36 & 1.02 \\
\hline Meat consumption (moderate) & $0.17 *$ & 0.10 & 0.28 & $0.24 *$ & 0.17 & 0.56 \\
\hline Fat consumption (high) & $4.47 *$ & 1.59 & 13.13 & $5.12 *$ & 1.43 & 15.32 \\
\hline (moderate) & $0.44 *$ & 0.26 & 0.73 & & & \\
\hline Egg consumption (high) & $0.05 *$ & 0.02 & 0.11 & $0.11 *$ & 0.09 & 0.34 \\
\hline (moderate) & $0.19 *$ & 0.10 & 0.39 & & & \\
\hline Coconut milk cons. (high) & $0.44 *$ & 0.20 & 0.92 & 0.53 & 0.23 & 1.03 \\
\hline (moderate) & $0.24 *$ & 0.14 & 0.40 & & & \\
\hline Fruit consumption (high) & $0.29 *$ & 0.14 & 0.58 & $0.32 *$ & 0.18 & 0.59 \\
\hline Vegetable consumption (high) & $0.54 *$ & 0.30 & 0.96 & 0.67 & 0.46 & 1.12 \\
\hline (moderate) & $0.34 *$ & 0.20 & 0.58 & & & \\
\hline Garlic consumption (high) & $0.44 *$ & 0.22 & 0.88 & 0.55 & 0.38 & 1.06 \\
\hline
\end{tabular}

* Significant risk assessed based on $95 \%$ Confidence Interval; OR = Odds Ratio; $95 \% \mathrm{CI}=95 \%$ Confidence Interval 
This study has identified that excessive exposure to sunlight was the main risk factor in the development of skin cancer among the Indonesian population. This excessive exposure to sunlight is reflected by low education level and working outside the buildings. High fat consumption was also identified as important risk factor for skin cancer, while the consumption of fruit could prevent its development.

Relative to increasing trend in the morbidity and mortality of cancer in Indonesia, ${ }^{18-21}$ the findings could be accounted for further planning of cancer control program.

\section{Acknowledgement}

We would like to thank the International Cancer Research Grant system, Monbusho, Japan and the Dean, Faculty of Medicine, University of Indonesia, Jakarta for his approval of the Japan-Indonesia Collaborative Study. This work has been supported by the Grant No. 09042004, under the Ministry of Education, Science, Sports and Culture, Government of Japan and was partly supported by the Indonesian Cancer Foundation, the Jakarta International Cancer Conference Fund and the Terry Fox Foundation, Canada. The collaborative study was initiated with Dean's approval No. 845/PT.02.H4.FK/E/97. We would also appreciate the Director of Dr. Cipto Mangunkusumo National Central General Hospital, for his technical support to finish this work. We are debtful for excellent assistance of Ms. Ros, Titien, Yeni and Mimin, the clinical and public health nurses in data collection.

\section{REFERENCES}

1. Demographic Study Center, NFPCB. Indonesian Demographic and Health Survey 1991. Jakarta, 1992.

2. Demographic Study Center, NFPCB. Indonesian Demographic and Health Survey 1994. Jakarta, 1995.

3. Cornain S, Mangunkusumo R, Nasar IM, Prihartono J. Ten most frequent cancer in Indonesia. Patology based cancer registry data of 1988-1992. In: Cancer in Indonesia.
National Cancer Registry Center, Jakarta Coordinating Board, 1997.

4. Suzuki T, Ueda M, Ogata K, Horikoshi T, Munakata N, Ichihashi M. Doses of solar-ultraviolet radiation correlate with skin cancer rates in Japan. Kobe J Med Sci 1996; 42: 375-88.

5. Amstrong BK, Holman CD. Malignant melanoma of the skin. Bulletin of WHO 1974; 45:245-52.

6. Corona R. Epidemiology of non-melanoma skin cancer: a review. Annal dell Instituic Superiore di Sanita. 1996; 32: 37-42.

7. English DR, Amstrong BK, Kricker A, Fleming C. Sunlight and cancer. Cancer Causes and Control 1997; 8: 271-83.

8. Kricker A, Amstrong BK, English DR. Sun exposure and non-melanocytic skin cancer. Cancer Causes and Control 1994; 5: 369-92.

9. Marks R. An overview of skin cancers. Incidence and causation. Cancer 1995; 75: 607-12.

10. World Health Organization. International Classification of Diseases. $10^{\text {th }}$ Revision, Geneve, 1990

11. Mausner IS, Bahn AK. Epidemiology: An Introductory Text. WB Saunders Co. 1974.

12. Schlesselman JJ Case Control Studies. New York: Oxford Univ.Press Inc., 1982.

13. Nutrition Directorate, MOH. Recommended Dietary Ailowances for the Indonesian Women: Manual for Nutritional Program. Jakarta, 1990.

14. Quinn AG. Ultraviolet radiation and skin carcinogenesis. Brit.J.Hop.Med. 1997; 58: $261-4$.

15. Beral $\mathrm{V}$, Robinson $\mathrm{N}$. The relationship of malignant melanoma, basal and squamous skin cancers to inddor and outdoor work. Br J Cancer 1981; 44: 886-91.

16. Weinstock MA, Colditz GA, Willet WC, Stampfer MJ, Rosner B. Speizer FE. Recall (Report) bias and realibility in the retrospective assessment of melanoma risk. Am J Epidemiol 1991; 133: 240-5.

17. Goldstein F, Speizer FE, Hunter DJ. A prospective study of incident squamous cell carcinoma of the skin in the nurses' health study. JNCI 1995; 87: 1061-6.

18. Research and Development Center, MOH. Indonesian National House Hold Survey 1980. Jakarta, 1981.

19. Research and Development Center, MOH. Indonesian National House Hold Survey 1986. Jakarta, 1987.

20. Research and Development Center, MOH. Indonesian National House Hold Survey 1992. Jakarta, 1993.

21. Tjarta A, Kanoko M, Mangunkusumo RR. Malignant melanoma and malignant epidermal tumors in Jakarta. Relative frequency and some histopathological aspects. Presented on $2^{\text {nd }}$ Congress Asia-Pacific Association Society of Pathologists, Philippine, 1991. 